\title{
Artificial Intelligence (AI)-Based Pronunciation Checker: An Alternative for Independent Learning in Pandemic Situation
}

\author{
Sari Dewi Noviyanti \\ Islamic State Institute of Jember \\ Sari.dewinoviyanti@gmail.com
}

\begin{abstract}
The primary aim of this study was to explore the effectiveness of using artificial intelligence-based pronunciation checker in learning pronunciation independently from the viewpoints of higher education students of English Education Department in IAIN Jember. Mix method were used as the research design. The quantitative data were obtained through one group pretest posttest design to know the effectiveness of the application to student's pronunciation achievement. Then, a questionnaire was used to investigate student's attitude toward the pronunciation application. The results of the speaking test showed that student's pronunciation was improved. The average score of student's pre-test score was increased for about 30 points, from 56 points to 90 points on post- test. The analysis of student's questionnaire demonstrated conceptions about using technology of doing independent learning especially in English pronunciation. The study suggests that while students admit the effectiveness of artificial intelligence technology in learning pronunciation independently, they still believe that having a real communication, especially with natives as frequently as possible, will help their pronunciation learning faster and better.
\end{abstract}

Keywords: artificial intelligence; independent learning; pronunciation checker

\section{BACKGROUND}

There are two main language competencies in language learning namely, productive and receptive language competencies. Ability to speak and write or producing language output categorized as productive competencies, while ability to receive information or input categorized as receptive competencies. However, speaking become the initial ability assessed and noticed when we have communication or conversation. Harmer (2007) states that the pronunciation or the way we produce words is the first noticeable thing that detected by the hearer. It is not arguable that grammar and vocabulary are important elements in language learning. However, without correct pronunciation, the conversation will be impossible to be conducted in proper way. People could understand grammar mistakes, and the conversation will still go on, but not when we produce incorrect words pronunciation. The communication could go wrong and almost impossible to be understood smoothly.

The main purpose of conducting teaching and learning process in any language is about helping students to communicate with target language users. But in reality, talking with teachers and friends in foreign language is considered as enough for many students. Though it is a big mistake. There are many reasons why this is called a mistake. First, bad English is approved among teachers and student's communication. Second, classroom communication between students conducted in a condition which they approved each other's mistakes and 
incorrect pronunciation. Third, the chance to speak with native speaker is rarely found by students which make the classrooms learnings are far from real situation.

Though the role of English pronunciation is emerged to be conducted in most proper way, this skill does not get enough attention from many educators. As (Gilakjani, 2018) states that the pronunciation of English is one of the fields that are least liked by educators to be taught in their classrooms. It also can be related to Hismanoglu and Hismanoglu (2011) statement that English pronunciation is rarely included to curriculum, it is because the focus of English teaching and learning is only at the four skills namely speaking, writing, listening and reading. Many teachers do not realize the importance of pronunciation. Teachers pay attention to grammar and vocabulary in learning foreign languages and they help students become skilled in listening and reading. Second, most teachers argued that learning pronunciation is not easy to be conducted and found tedious by students (Fromkin, Rodman, \& Hyams 2014). Those arguments then be debated by (Levis \& Suvorov, 2014) which stated that English pronunciation teaching and learning problems commonly caused by inappropriate teaching materials and time limitation which make the pronunciation practices are not sufficient enough for students. Other problems found, paying attention to pronunciation practices is just a waste of time and takes lots of energy. Pronunciation ability is considered as a skill which can be learned by students independently without any specific instruction from the teachers.

From preliminary research that has been done, it was found that learning pronunciation in class does not use teaching materials. In addition, learning in the classroom is still dominated by presentation activities. Lecturers also have limited time to check the pronunciation ability of all students so that the development of the ability of each student cannot be measured with valid. Based on the problems mentioned above, this research aimed to apply and to check the effectiveness of an Android application-based intelligence artificial spell checker that is able to check the pronunciation of each student accurately and measurably.

(McCrocklin, 2014) conducted a study on improving students' pronunciation skills by applying pronunciation learning based on sound detection technology. The conclusion of the research when learning is integrated with technology, can help students feel more independent, especially in terms of pronunciation. (Nurhayati, 2015) researched the use of games to improve the pronunciation skills of elementary students. The results of the study show that with the use of games, pronunciation learning becomes more fun. (Cakici, 2016) in his research found that the implementation of technology in the context of foreign language learning can improve problem solving skills and provide opportunities for students to use high-level skills and make a development of critical thinking and process of information become easier. Technology also encourages independency of learning, support autonomous learning and promote collaborative language learning that is active, motivates and facilitates language learning and enhances the ability of teachers. Thus, technology is very important to be integrated into teaching foreign languages as an effective complementary tool.

(Benzies, 2017) in his research entitled the contribution of technology to the teaching of pronunciation competence shows students really like learning pronunciation which is integrated with technology. The results indicate that students prefer pronunciation learning that is integrated with technology compared with conventional learning. (Neri, Mich, Gerosa, \& Giuliani, 2017) in her experiment also found that pronunciation training with a computeraided system with a simple automatic speech recognition component can improve the ability 
of students compared to conventional pronunciation teaching. (Fathira \& Utami, 2019) conducted a classroom action research to students of STIBA Persada Bunda. This research aimed to improve students" pronunciation of ending "s" sound. This research proved that the use of android application in application store could improve students' pronunciation, especially sounding ending "s". Another research done by (Aditya, 2016) which focused on the development of speak app as an android application to improve students speaking competence. This research revealed that the use of technology could significantly improve students speaking competency. Gilakjani (2018) conducted a research about teachers' perspective about the use of technology to teach pronunciation competence. The result of this research showed that teachers felt interested to use technology to teach pronunciation because it has higher level of pronunciation accuracy.

Those researches have similarities with this research as the focus of how to implement technology in teaching. However, this research has its distinction since it is focus on the implementation of spell checker android application which is easy to use by students independently. This is a special android application because it could validate someone' pronunciation is correct or wrong, it has locked-learning stages features and complete sounds exercises. This research will focus on the effectiveness of an application assisted with Android which based on artificial intelligence to detect whether a pronunciation is correct or still needs to be corrected again. The existing technology is only limited to sound detection that will transmit sound into text form. But until now there has been no application that can be a helper position as a teacher who is able to state that a pronunciation is declared true or not true.

\section{METHOD}

The mix method was applied in this research to know the effectiveness of the implementation of spell checker. Quantitative data was obtained by doing one group pretest posttest to know the effectiveness of the application to improve student's pronunciation. Qualitative data was obtained through questionnaire to gather students or user perceptions and attitudes about this application. Data were analyzed through descriptive analysis.

\section{Participants}

Thirty students participated in the study. Purposive sampling was used as the technique for data sampling. It consists of ten male students and twenty female students.

\section{Instruments}

To obtain the quantitative data, a pronunciation test was conducted. The test aimed to check the accuracy of the words pronounced by students. A speaking instrument test was used to conduct the test. The test showed the level of effectiveness of the spell checker.

For qualitative data, a questionnaire was prepared by the researcher. The questionnaire was composed of twelve questions, with two options, namely, 'agree' and 'disagree'. The questionnaire items were prepared and developed based on some previous and relevant literatures. The number of reliability coefficient for the instrument was .075 , which categorized as moderate reliability, so then it can be concluded that the instrument is reliable enough to use in this research.

\section{FINDINGS}

Tests were carried out using the one group pretest-posttest design method to determine the impact of pronunciation checker on respondents. Based on table 1, testing was carried out 
2 times, before (P1) using the application and after using the application (P2). Based on the result of the tests, it can be seen that the increase occurred before and after using the spell checker.

Table 1. Students tests result

\begin{tabular}{ccc}
\hline Topic & P1 \% (Pretest) & P2 \% (Posttest) \\
\hline Silent s & 76,67 & 86,67 \\
Silent k & 53,33 & 90,00 \\
Silent h & 46,67 & 86,67 \\
Silent b & 50,00 & 90,00 \\
Silent t & 56,67 & 93,33 \\
\hline
\end{tabular}

From the results of the tests that have been carried out in table 2, it can be seen that student's pronunciation accuracy is improved. In the first statement there is an increase in the percentage from $76,67 \%$ to $86,67 \%$ for material silent $s$, in the second statement there is an increase from $53,33 \%$ to $90,00 \%$ for material silent $\mathrm{k}$, in the third statement there is an increase from $46,67 \%$ to $86,67 \%$ for material silent $\mathrm{h}$, then in the fourth statement there is an increase from $50 \%$ to $90 \%$ and in the last statement there was an increase from $56,67 \%$ to $93,33 \%$ for material of silent $b$ and silent $t$. Based on the result, it can be seen that student's score were increased 33 points from average score of 56 on pre-test to 90 on posttest.

The result of students' perspective and attitude about the pronunciation checker is presented on the table below

Table 2 Students' beliefs on the value of using spell checker

\begin{tabular}{clcc}
\hline No & \multicolumn{1}{c}{ Statement } & Agree \% & Disagree \% \\
\hline 1 & $\begin{array}{l}\text { I believe that the application has pedagogical value } \\
2\end{array}$ & $\begin{array}{l}\text { I believe that this application can improve my } \\
\text { pronunciation }\end{array}$ & 96,67 \\
3 & $\begin{array}{l}\text { I believe that this application gives opportunities to } \\
\text { improve my pronunciation accuracy }\end{array}$ & 96,67 & 3,33 \\
4 & $\begin{array}{l}\text { I think that students need to use this application to } \\
\text { increase their pronunciation accuracy }\end{array}$ & 96,67 & 3,33 \\
\hline
\end{tabular}

Based on the result of first question, it can be seen that most of students believe that the application could increase their pronunciation accuracy. The results of question three indicates that all of the participants are agree that the application provide learners with opportunity to promote their skills in pronouncing words. Question four asked participants whether the spell checker application should be used by other students or not. It reveals that almost all of the participants, 96,67\%, agree with the idea that the spell checker application should be used for English learners to help them improving their pronunciation accuracy. In short, Table 2 reveals that although some students do not think that the spell checker have any value, majority of students think that the application has pedagogical value, especially to improve student's pronunciation skill.

Table 3 students' attitude toward the application

\begin{tabular}{llll}
\hline No & Statement & Agree \% & Disagree \% \\
\hline
\end{tabular}




\begin{tabular}{clcc}
\hline 5 & $\begin{array}{l}\text { I believe that I cannot improve my pronunciation by this } \\
\text { application }\end{array}$ & 30,00 & 70,00 \\
6 & $\begin{array}{l}\text { I believe that this application cannot support } \\
\text { independent learning }\end{array}$ & 13,33 & 86,67 \\
7 & I believe that this application can be time consuming & 10,00 & 90,00 \\
8 & I find it difficult to use this application & 26,67 & 73,33 \\
\hline
\end{tabular}

The table shows that most of students do not agree with the statement that the spell checker cannot improve student's pronunciation skill. In other statement, eighty percent of students stated that this application can support their independent learning, because this application substitute teacher's role to check student's pronunciation. Ninety percent of students also disagree with the idea that This application is needs much time allotment. Question eight indicates that most of students do not find difficulties to operate or use the spell checker. Generally, students showed to have a good attitude to this android application.

Table 4 proofs that most of students are considering the fact that the spell checker application is an effective media to improve student's pronunciation.

Table 4 spell checker effectiveness

\begin{tabular}{clcc}
\hline No & \multicolumn{1}{c}{ Statement } & Agree \% & Disagree \% \\
\hline 9 & $\begin{array}{l}\text { I believe that this application can decrease my anxiety } \\
\text { toward pronunciation learning }\end{array}$ & 36,67 & 63,33 \\
10 & $\begin{array}{l}\text { I believe that this application is not too effective for } \\
\text { pronunciation learning }\end{array}$ & 13,33 & 86,67 \\
11 & $\begin{array}{l}\text { I believe that this application promotes pronunciation } \\
\text { accuracy } \\
\text { I believe that this application promotes independent } \\
\text { learning }\end{array}$ & 13,33 & 83,33 \\
\hline
\end{tabular}

Question nine was asked to students to reveal how they feel about the spell checker could improve their confidence in pronunciation learning. The results indicate that many students feel that this application lower their anxiety in learning pronunciation. Question ten indicates that majority of students stated that the spell checker is an effective application for their pronunciation learning.

\section{DISCUSSION}

English language teaching and technology cannot be separated. There is a rapid development and implementation of technology to promote an effective language teaching. The results of this research support others previous research about the implementation of technology in English language teaching. Benzies (2017) research showed that students really like learning pronunciation which is integrated with technology. The research results indicated that students prefer pronunciation learning that is integrated with technology compared with conventional learning. Neri (2017) in her experiment also found that pronunciation training with a computer-aided system with a simple automatic speech recognition component can improve the ability of students compared to conventional pronunciation teaching. (Fathira \& Utami, 2019) conducted a classroom action research to students of STIBA Persada Bunda. This research aimed to improve students' pronunciation of ending "s" sound. This research proved that the use of android application in application store could improve students' 
pronunciation, especially sounding ending " $\mathrm{s}$ ". One to be stressed is, the existence of technology at class is not for teacher's replacement. Technology is adapted not to substitute, but as a compliment to help teachers improve the quality of learning.

The development of spelling checker is needed to provide students with independent and free of time limitation chances for their pronunciation training and exercise experience. Providing students with pronunciation training is important since pronunciation needs time to perfect them. As (Roccamo, 2014) stated that it is vital to provide L2 learners with two skills: 1) the ability to produce what is currently being trained in a more accurate manner, and 2) the ability to notice and attend to their own pronunciation and that of others. This spelling application trains students to produce words production and to check how it is compared with what native and advanced speakers have. By knowing the correct pronunciation, they are able to produce the new or similar sounds themselves permanently.

Technology and education are both dynamic. As we can see, technology of education movement in such way. We found that after a computer integration, now educational technology moves into something which is more mobile and quick access. Android is one of the top mobile phone platforms which has high users especially in Indonesia. That is why, this learning application which supported by Android will make the application is easier to be accessed. Learning through mobile phone now became a trend. Parents, teachers and students often to install any application which can support their learning process. This action is based on the beliefs that those application has a pedagogical value for them. They feel an improvement, knowledge elevation and increase in some life aspects. A research from (Zhang, 2016) showed that a teacher and students' attitude in choosing mobile application for learning will help them to maximize the advantages of the applications itself. The wiser they use, the greater benefits taken. Another research from (Jati, 2018) also stated that some useful application can be used for self-study and they are really helpful to improve students English learning. The spell checker application in this research is an android application which integrated with artificial intelligence. Basically, this application is easy to use because it can be installed on mobile phone. The artificial intelligence used to detect learners pronouncing words and notice them whether their pronunciation is already correct or wrong.

This research proves that an education is about improvement. Development and implementation of this spell checker is about integrating pedagogical value and technology to promote students independent learning. Self-learning or Independent learning does not mean students can stand alone without teacher guidance. Independency here is the way students could access knowledge freely, validate it and confirm it even their teacher in distance. Independent learning is needed in this pandemic situation. While teaching and learning cannot be conducted at class, students still able to improve themselves pedagogically. As (Jati, 2018) stated that teachers who eager to dig more information about learning application and technology, and they desire to learn and to use it in real teaching practices will find many potentials of how technology could really help us in teaching and learning process. So, distance and an absence of physical teachers would be not become a problem when students able to explore a suitable technology for learning.

Finally, the result of this research shows that this spell checker application is effective to improve student's pronunciation accuracy. This spell checker also promotes independent learning that students could access it easily and take an advantage from it, and apply the pedagogical value in wider context and area. 


\section{CONCLUSION}

The primary aim of this study was to explore the effectiveness of using spell checker learning English pronunciation from the viewpoints of EFL students. The result of one group pretest-posttest showed that there was an increase in students speaking results. Students had significant improvement on their pronunciation after using the application. Based on the tests that have been carried out, it can be concluded that the spell checker has an impact on increasing student's pronunciation skill. Related to student's perceptions and attitudes about this application, most of students agree that this spell checker is effective to promote students independent learning on English words pronunciation. However, based on further statement, students stated that even there is a good lecturer, good application helping them to learn English pronunciation, having a chance to communicate with native frequently is still their wish and desire to improve their pronunciation faster and better.

\section{REFERENCES}

Aditya, D. (2016). Speak Up An Android Application Model to Improve The Midwifery Students' Speaking Competence. Unpublished Master Thesis. English Language Studies Department: Sanata Dharma University Yogyakarta

Benzies Y. (2017). Contributions of new technologies to the teaching of English pronunciation. Journal of Language Value, 9(1), 135.

Cakici, D. (2016). The Use of ICT in Teaching English as a Foreign Language. Participatory Educational Research Journal. 2016(IV), 73-77

Fathira, V \& Utami, S. (2019). Implementing an Android-based Learning Media Application to Improve Learners' Ability in Pronouncing Ending -s. Journal of English for Academic. 6( 2)

Fromkin, V., Rodman, R., \& Hyams, N. (2014). An introduction to language (10th ed.). Cengage Learning

Gilakjani, P. (2018). Teaching Pronunciation of English with Computer Technology: A Qualitative Study. International Journal of Research in English Education. DOI: 10.29252/ijree.3.2.94

Harmer, J. (2007). The practice of English language teaching. Pearson. Retrieved 18 September 2020 from www.worldcat.org/title/practice-ofenglish-languageteaching/oclc/149005881

Hismanoglu, M., \& Hismanoglu, S. (2011). Internet-based Pronunciation Teaching: An Innovative Route toward Rehabilitating Turkish EFL Learners' Articulation Problem. European Journal of Educational Studies, 3(1), 23-36.

Jati, A.Gumawang. (2018). The Use of Smartphone Applications In English Language Teaching. Jurnal Sosioteknologi, 17( 1 )

Levis, J. \& Suvorov, R. (2014). Automated speech recognition. Chapelle Publisher. USA

McCrocklin, S. (2014). Pronunciation in Second Language Teaching. 5th Annual Proceedings of University Iowa.

Neri, A., Mich O., Gerosa, M., \& Giuliani, D. (2017). The effect of computer assisted pronunciation training (CAPT) system to improve word-level pronunciation skills in English as a foreign language. Journal of Coumputer and Language Learning 
Nurhayati, D. (2015). Improving Students' English Pronunciation Ability through Go Fish Game and Maze Game. Journal of Dinamika Ilmu. IAIN Samarinda

Roccamo, A. (2014). Effective pronunciation instruction in basic language classrooms: A modular approach. In J. Levis \& S. McCrocklin (Eds). Proceedings of the 5 th Pronunciation in Second Language Learning and Teaching Conference (pp. 183-189). Ames, IA: Iowa State University

Zhang, S. 2016. Mobile English Learning: An Empirical Study on an APP, English Fun Dubbing. iJET - Volume 11, Issue 12, 2016. https://doi.org/10.3991/ijet.v11i12.6314 